\title{
Kehl, M. R. (2015). O tempo e o cão: a atualidade das depressões (2a ed.). São Paulo: Boitempo.
}

DOI: 10.22289/2446-922X.V4N2A8

\section{Salete Cristina Mendes da Silva Costa Leonardo Carrijo Ferreira ${ }^{1}$}

A obra 'O tempo e o cão' de Maria Rita Kehl baseia-se na teoria de que a depressão além de ser um sintoma de sujeitos em sofrimento se tornou um sintoma social. Ressalta-se à construção da sociedade moderna e tecnológica - ao passo que possui tempo para tudo não possui tempo para nada. Kehl afirma que as pessoas não sofrem apenas pelos motivos que as deixam tristes - perdas, desemprego, problemas familiares - mas sim pelo fato de estarem sofrendo em uma sociedade que visa a felicidade e a totalidade.

$\mathrm{Na}$ obra em questão a autora deixa visível à necessidade da depressão ser detalhada principalmente no campo psicanalítico. Ao fazer este detalhamento além de lançar mão de seus conhecimentos ela utiliza-se de outros conhecedores como Lacan e Freud.

Para tanto, a autora baseia-se na afirmação de que a depressão é um sintoma social. É para fortalecer tal afirmação ela se apoia na história, isto é, em cada momento histórico é possível demarcar o mal-estar advindo do modo de cultura e de vida. Logo, a melancolia ocupou local de destaque desde a Idade Média até meados da Modernidade.

Dessa forma, os depressivos são ditos como a má notícia que ninguém quer saber. "A depressão é a expressão de mal-estar que faz água e ameaça afundar a nau dos bem-adaptados ao século da velocidade, da euforia, prêt- à- porter, da saúde, do exibicionismo e, como já se tornou chavão, do consumo generalizado" (Kehl, 2015 p.22). Todavia, esta má notícia está presente e vem aumentando cada vez mais em nossa sociedade causando a necessidade de ser evidenciada.

Com isso, para melhor entender o discurso de Maria Rita acerca da reflexão existente entre os depressivos e o meio social é preciso levar em consideração o tempo ou a escassez dele, o excesso, o consumo e outras configurações que caracterizam as sociedades modernas.

\footnotetext{
${ }^{1}$ Endereço eletrônico de contato: p.i.i.h@hotmail.com Recebido em 16/03/2018. Aprovado pelo Conselho Editorial e aceito para publicação em 27/04/2018.
}

Rev. Psicol Saúde e Debate. Jul., 2018:4(2):130-133. 
Assim, a obra organizada se encontra em três partes: 'Da melancolia às depressões', 'O tempo e o cão' e 'O recuo do depressivo' respectivamente.

Na primeira parte, 'Da melancolia às depressões', seção que Kehl explora a melancolia e a privatização de seu tratamento, faz isto se utilizando de conceitos freudianos. A autora mostra que Freud no fim do século XIX e início do XX, por meio de saberes psiquiátricos, mudou paradigmas acerca desta clínica.

Além disso, desde a Antiguidade Clássica a melancolia representava simbolicamente alguém que perdeu seu lugar próximo ao Outro.

"A melancolia antes de Freud - mas também antes de ser entendida como um distúrbio a ser curado pela medicina psiquiátrica - era vista como uma forma de mal-estar que denunciava o desajuste entre alguns membros" (Kehl, 2015, p.44).

Ainda na primeira parte da obra em questão Maria Rita para expor uma vertente contrária à freudiana utiliza-se dos conceitos de Walter Benjamim e da análise do romantismo e da melancolia feita por ele. Nesta análise Benjamim caracteriza o melancólico como sujeito separado da vida pública e das convicções coletivas hegemônicas sobre a ética e a moral este desacordo resulta na melancolia. Em outras palavras a melancolia acontece quando o sujeito recua frente à falta de perspectivas sociais e individuais e se adere a atitudes fatalistas.

Em contrapartida, não é estranho à atualidade em que o consumo impera e organiza o laço social - o retorno deste lugar afastado, então seria depressão, que segundo a conceituação feita na obra de Kehl é [...] o nome contemporâneo para os sofrimentos decorrentes da perda do lugar dos sujeitos junto à versão imaginária do Outro [...] (Kehl,2015, p.49). Essa perda de lugar, principalmente da vida pública, atinge negativamente o sentimento de ser e não faz correspondência com os ideais de bem-estar.

Para tanto, ressalta-se na segunda parte 'O tempo e o cão', a questão da temporalidade - a relação entre o aumento de casos de depressão e a urgência do tempo na atualidade utilizando-se de fundamentos teóricos como os de Lacan e filosóficos de Bergson.

É importante ressaltar que as várias formas de organização e de percepção subjetiva do tempo é o que caracteriza a temporalidade. O uso do tempo varia de acordo com a cultura, uma certeza é que na atualidade a cada segundo é necessário fazer uma escolha o que gera a urgência.

Além disso, a urgência de tempo, esta rapidez impede o sujeito de apreciar o verdadeiro valor das experiências. A autora usa o exemplo da tecnologia que insiste em criar aparelhos para facilitar a vida e aumentar o tempo livre das pessoas, mas como é notório na atualidade acontece exatamente o contrário. 
Com isso, tal comportamento gera o empobrecimento da experiência humana advindo do desenvolvimento da ciência, que cada vez mais comprime o tempo da fantasia e da convivência que se fazem tão necessárias na construção da vida humana.

A autora deixa a mostra nesta parte a importância do tempo na vida e na sociedade: "O tempo é uma construção social. Toda ordem social é marcada, à sua maneira, pelo controle do tempo; essa talvez seja a face mais invisível e mais onipresente do seu poder (Kehl, 2015, p.110)."

Contudo, o homem moderno, contemporâneo, vive totalmente imerso na temporalidade marcada por relógios que se assemelham a prisões, muitas vezes é pensado que não é possível estar no mundo atual e alheio a velocidade das coisas.

$\mathrm{Na}$ terceira parte, 'O recuo depressivo', seção que Kehl investiga a depressão do ponto de vista da psicanálise. Para tanto, a autora deixa claro que a depressão e seu respectivo tratamento é algo que gera dificuldades, pois está mais próximo da clínica das neuroses do que das psicoses. A depressão vai além de estados de ânimos - tristezas, abatimento, desânimo e também não deve ser confundida com as ocorrências depressivas esporádicas dos neuróticos.

Depreende-se de algumas peculiaridades é o que caracterizam a depressão. A autora afirma que o depressivo se abate por não ter experimentado outra forma de conhecer o mundo senão pela ótica da depressão.

Assim, nessa parte a autora aborda a clínica da depressão vista do ângulo da psicanálise. Isso é iniciado pela separação das diferenças mentais que existem entre a depressão e a melancolia. Maria Rita mostra a subjetividade dos depressivos e as causas que determinam episódios de depressão nos obsessivos e nos histéricos.

Ao apreciar a obra 'O Tempo e o cão: a atualidade das depressões' de Maria Rita Kehl é possível o fazer de duas maneiras distintas. A primeira é sob o ponto de vista interno, com isso é possível perceber que apesar de ser escrita em $1^{\text {a }}$ pessoa - algo que remete a subjetividade é escrita de forma lógica. Ser escrita deste modo não retirou a universalidade da obra, por mais que seja no princípio complexa acaba resultando no final uma clareza. Além disso, a estruturação da obra adotada por Kehl em dividir o livro em partes - é bastante original e facilita o entendimento do leitor. E a segunda é sob o ponto de vista externo, pois tal obra contribui bastante no entendimento da depressão sob o olhar da autora e de alguns autores citados por ela. Defendendo a teoria de que a depressão é um sintoma social, o qual muitas vezes a própria sociedade tenta esconder e fingir que não vê.

Dado o exposto, o presente estudo apresenta uma sólida contribuição em especial interesse para estudantes em psicologia e psiquiatria, graduandos, pôs- graduandos e mestres que desejem enriquecer seus conhecimentos acerca da problemática. Além disso, pode ser 


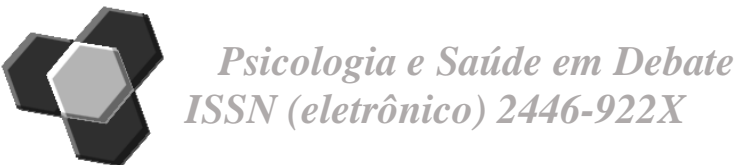

indicado a leitores curiosos pelo saber que pretendem aumentar ainda mais o conhecimento sobre 0 assunto.

Rev. Psicol Saúde e Debate. Jul., 2018:4(2):130-133. 